\title{
A hematologic condition expressed as a lung disease [version
}

\section{1; peer review: 2 approved, 1 approved with reservations]}

\author{
Mónica Egozcue-Dionisi1 , José Nieves-Nieves , Ricardo Fernández-Gonzalez¹, \\ Rosángela Fernández-Medero', Raúl Reyes-Sosa¹, José Lozada-Costas², \\ Ramiro Pérez-Duardo ${ }^{3}$, Román Vélez-Rosario ${ }^{3}$ \\ ${ }^{1}$ Pulmonary Medicine Department, San Juan City Hospital, San Juan, Puerto Rico \\ ${ }^{2}$ Hematology \& Oncology Department, San Juan City Hospital, San Juan, Puerto Rico \\ ${ }^{3}$ Pathology Department, University of Puerto Rico School of Medicine, San Juan, Puerto Rico
}

\author{
V1 First published: 12 Oct $2012,1: 28$ \\ https://doi.org/10.12688/f1000research.1-28.v1 \\ Latest published: 12 Oct 2012, 1:28 \\ https://doi.org/10.12688/f1000research.1-28.v1
}

\section{Abstract}

Pleural involvement secondary to Multiple Myeloma is considered a very rare complication. According to the literature only $1 \%$ of these patients develop a myelomatous pleural effusion. We present a case of a 39 year old man with multiple myeloma diagnosed six years prior to our evaluation, which developed progressive dyspnea, dry cough and right pleuritic chest pain two weeks prior to admission. On physical examination the patient had decreased breath sounds over the right posterior hemithorax accompanied by dullness to percussion. The chest radiogram was consistent with a right sided pleural effusion. Pleural fluid analysis revealed the presence of abundant abnormal plasma cells. The patient died four weeks after hospitalization. The presence of myelomatous pleural effusion is considered to be a poor prognostic finding, no matter at what disease stage it develops. So far no definite treatment has been shown to improve survival.

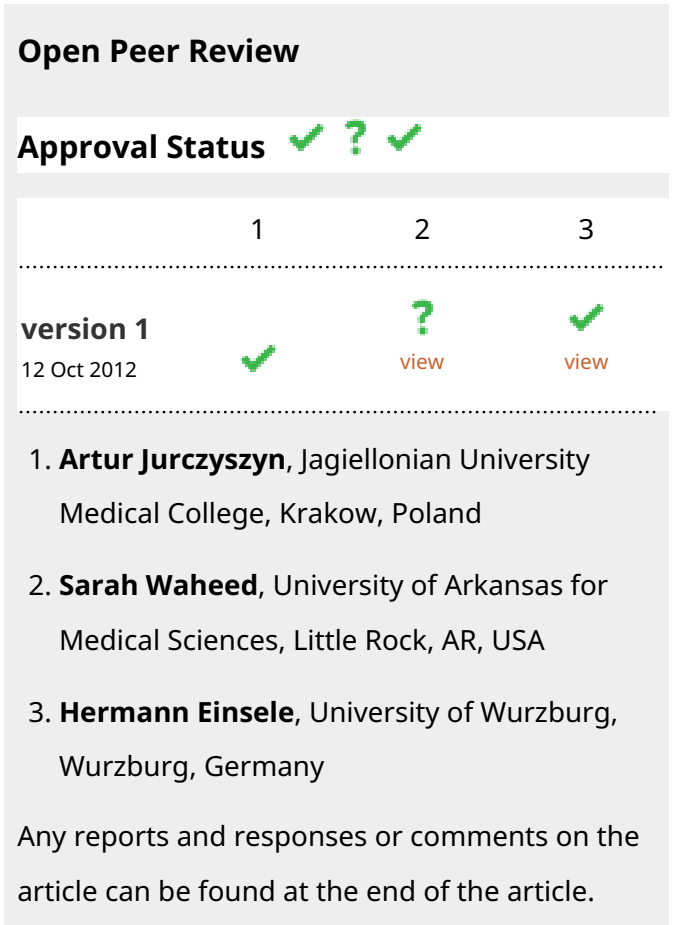

Corresponding author: Mónica Egozcue-Dionisi (monicaegoz@gmail.com)

Competing interests: No competing interests were declared.

Grant information: The author(s) declared that no grants were involved in supporting this work.

Copyright: ( 2012 Egozcue-Dionisi $\mathrm{M}$ et al. This is an open access article distributed under the terms of the Creative Commons Attribution License, which permits unrestricted use, distribution, and reproduction in any medium, provided the original work is properly cited. Data associated with the article are available under the terms of the Creative Commons Zero "No rights reserved" data waiver (CC0 1.0 Public domain dedication).

How to cite this article: Egozcue-Dionisi M, Nieves-Nieves J, Fernández-Gonzalez $\mathrm{R}$ et al. A hematologic condition expressed as a lung disease [version 1; peer review: 2 approved, 1 approved with reservations] F1000Research 2012, 1:28

https://doi.org/10.12688/f1000research.1-28.v1

First published: 12 Oct 2012, 1:28 https://doi.org/10.12688/f1000research.1-28.v1 


\section{Introduction}

Multiple Myeloma (MM) is a malignant neoplasm characterized by abnormal proliferation of plasma cells. The disease is typically manifested by anemia, pathologic fractures, hypercalcemia and renal failure. Pleural involvement in MM is very rare and seldom has been described in the literature. To our knowledge, approximately eighty cases have been mentioned in the largest case series reported. Pleural effusions can be either myelomatous or non-myelomatous, the former being the less common presentation. Most cases of myelomatous pleural effusions are due to IgA MM. We present a case of a patient with a pleural effusion secondary to IgG MM.

\section{Case report}

A 39 year old man with hypertension, end-stage renal disease and chronic smoker, diagnosed with MM six years prior to our evaluation, came to our institution complaining of progressive dyspnea, fever, and dry cough of two weeks of evolution. He was treated with a course of oral antibiotics for five days with minor symptom improvement. On admission the patient was found with a temperature of $37.8^{\circ} \mathrm{C}$, heart rate was 118/min., respiratory rate was 24 breaths/min., blood pressure was $120 / 74 \mathrm{mmHg}$, and oxygen saturation by pulse oximetry was $100 \%$ with a venturi-mask at $50 \% \mathrm{FIO}_{2}$. Chest examination revealed multiple bilateral palpable plasmacytomas along the anterior and posterior hemithorax with decreased breath sounds below the right scapular area, and percussion dullness was heard on the right side. Antero-posterior chest radiogram showed a large right side pleural effusion with contralateral shifting of the mediastinal structures and patchy airspace opacities throughout the left lung (Figure 1). Completeblood countrevealed pancytopeniawithaWBC of $2.8 \times 109 / 1, \mathrm{Hb}$ of $8.4 \mathrm{~g} / \mathrm{dl}$ and platelet count of $19 \times 10^{9}$. Blood chemistry showed a protein of $5.6 \mathrm{~g} / \mathrm{dl}$ and lactate dehydrogenase of $721 \mathrm{IU} / \mathrm{l}$. Calcium levels were within normal limits. Diagnostic and therapeutic thoracentesis was performed after platelet transfusion and a total of
$900 \mathrm{ml}$ of turbid, sero-sanguinous fluid was removed. Pleural fluid analysis was consistent with an exudate and the fluid cytology revealed the presence of abundant atypical plasma cells (Figure 2). Bacteria, fungi and acid fast smear and cultures of the pleural fluid were reported negative. The patient's clinical condition was aggravated by bacteremia, septic shock and respiratory failure requiring mechanical ventilation. The patient was complicated by sepsis and died four weeks after hospitalization.

\section{Discussion}

Extra-medullary involvement in MM is considered to be a rare complication of the disease ${ }^{1}$. Commonly involved sites are the nasal cavity, lung, pleura, thoracic wall, central nervous system, lymph nodes, spleen, skin and eyes. Involvement of serous cavities such as the pleural cavity, peritoneal cavity, cerebral-spinal space and pericardium is unusual, the pleural cavity being the most common site $^{2}$. Pleural effusions occur in $6 \%$ of the patients with multiple myeloma and can be myelomatous or non-myelomatous ${ }^{3-5}$. Nonmyelomatous pleural effusions can occur secondary to sepsis, pulmonary embolism, chronic renal failure and secondary neoplasm ${ }^{6}$. On the other hand, myelomatous pleural effusions have been described in only in $1 \%$ of the patients with MM and the diagnosis is based on the demonstration of monoclonal proteins in the pleural fluid by protein electrophoresis, finding monoclonal plasma cells in the fluid and/or histological examination of the pleura through biopsy ${ }^{7,8}$. Literature reveals that almost $40 \%$ of the cases of myelomatous pleural effusions are due to $\operatorname{IgG}$ type ${ }^{6}$.

Multiple treatment regimens have been used including VAD regimen (vincristine, doxorubicin and dexamethasone), prednisolone, melphalan, etoposide, stem cell rescue and pleurodesis without a significant effect on mortality ${ }^{6,9}$. The use of bortezomib, a protease inhibitor, in refractory multiple myeloma has shown promising

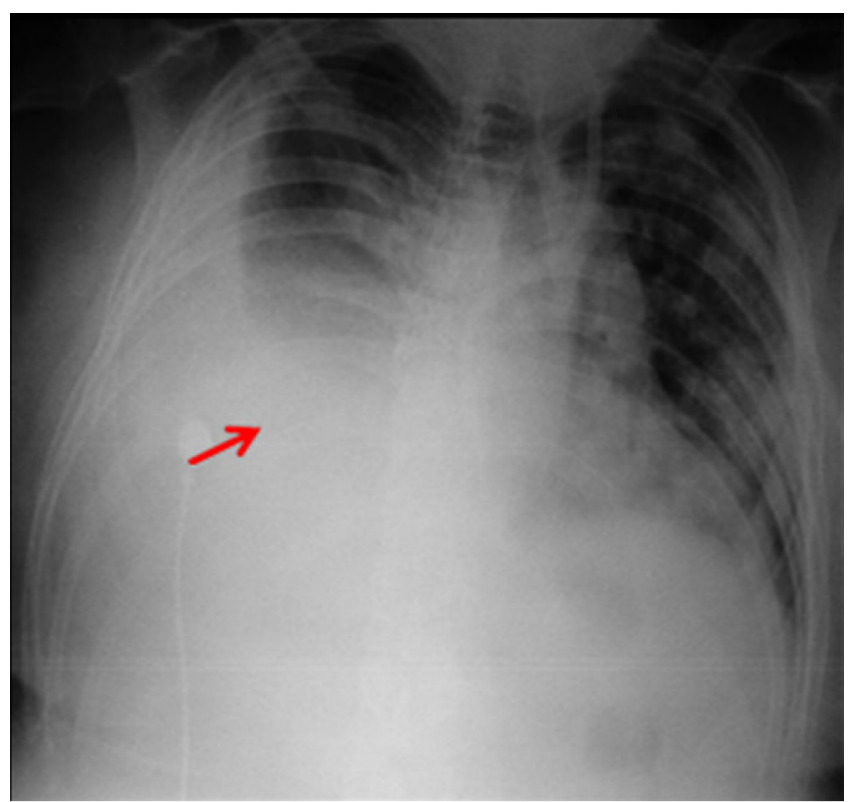

Figure 1. Antero-posterior chest $\mathrm{x}$-ray on admission showing right-sided pleural effusion.

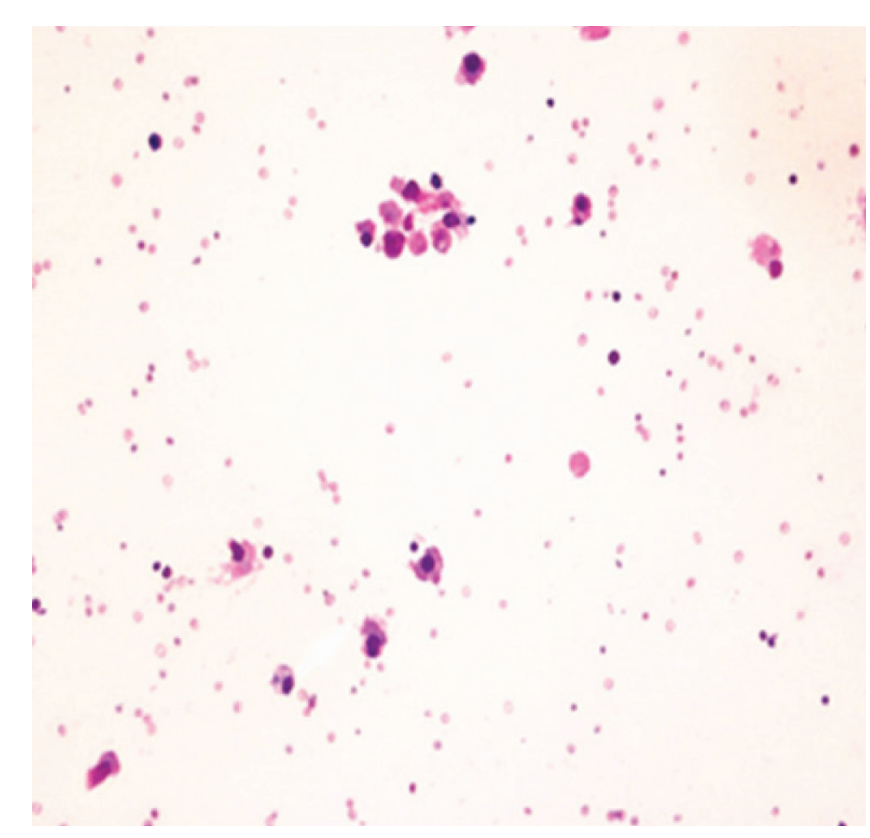

Figure 2. Photomicrograph of pleural fluid showing atypical plasma cells (Giemsa stain $x$ 400). 
results. There is a single case of refractory MM and myelomatous pleural effusion treated successfully with intravenous and intrapleural bortezomib ${ }^{2,10}$.

\section{Conclusion}

There has been limited information in the literature regarding pulmonary manifestations of this hematologic malignancy. Pleural effusions can be present as an initial manifestation of the disease or as the disease progresses. As in our case, pleural involvement is associated with poor prognosis and high mortality rate no matter at what disease stage it appears. So far, there are no proven treatment regimens that can halt disease progression. Physicians should be aware of such a fatal complication as it predicts a very poor outcome. For this reason, additional studies towards the development of new treatment strategies should be considered.

\section{Consent}

Written informed consent for publication of clinical details and clinical images was obtained from the relative of the patient.

\section{Author contributions}

Authors have contributed to the literature review, drafting of the manuscript, revisions of the manuscript and have agreed to the final content.

\section{Competing interests}

No competing interests were declared.

\section{Grant information}

The author(s) declared that no grants were involved in supporting this work.
1. Ghosh S, Gopal R, Advani SH: Myelomatous pleural effusion. J Assoc Physicians India. 2006; 54: 738-9. PubMed Abstract

2. Kim YJ, Kim SJ, Min K, et al.: Multiple myeloma with myelomatous pleural effusion: A case report and a review of the literature. Acta Haematol. 2008; 120(2): 108-111.

PubMed Abstract | Publisher Full Text

3. Rodriguez JN, Pereira A, Martínez JC, et al:: Pleural effusion in multiple myeloma. Chest. 1994; 105(2): 622-4. PubMed Abstract | Publisher Full Text

4. Sasser RL, Yam LT, Li CY: Myeloma with involvement of the serous cavities. Cytologic and immunochemical diagnosis and literature review. Acta Cytol. 1990; 34(4): 479-485. PubMed Abstract

5. Kintzer JS Jr, Rosenow EC 3rd, Kyle RA: Thoracic and pulmonary abnormalities in multiple myeloma. Arch Intern Med. 1978; 138(5): 727-730.

PubMed Abstract | Publisher Full Text
6. Malhotra KP, Agrawal V, Prasad N: Myelomatous pleural effusion: A diagnostic challenge. Indian J Cancer. 2010; 47(3): 351-352. PubMed Abstract | Publisher Full Text

7. Palmer $\mathrm{HE}$, Wilson $\mathrm{CS}$, Bardales $\mathrm{RH}$ : Cytology and flow cytometry of malignant effusions of multiple myeloma. Diagn Cytopathol. 2000; 22(3): 147-151. PubMed Abstract | Publisher Full Text

8. Shirai T, Hashizume I, Kasamatsu N, et al: A case of Bence-Jones proteinlambda positive multiple myeloma complicated by abnormal plasma cells in pleural effusion. Nihon Kokyuki Gakkai Zasshi. 1998; 36(2): 176-81. PubMed Abstract

9. Kamble R, Wilson CS, Fassas A, et al:: Malignant pleural effusion of multiple myeloma: Prognostic factors and outcome. Leuk Lymphoma. 2005; 46(8): 1137-42.

PubMed Abstract | Publisher Full Text

10. Iannitto $\mathrm{E}$, Minardi $\mathrm{V}$, Tripodo $\mathrm{C}$ : Use of intrapleural bortezomib in myelomatous pleural effusion. Br J Haematol. 2007; 139(4): 621-622.

PubMed Abstract | Publisher Full Text 


\section{Open Peer Review}

\section{Current Peer Review Status:}

\section{Version 1}

Reviewer Report 12 November 2012

https://doi.org/10.5256/f1000research.201.r316

(C) 2012 Einsele H. This is an open access peer review report distributed under the terms of the Creative Commons Attribution License, which permits unrestricted use, distribution, and reproduction in any medium, provided the original work is properly cited.

\section{Hermann Einsele}

Department of Internal Medicine II, University of Wurzburg, Wurzburg, Germany

The response quality following high-dose chemotherapy and autologous stem cell transplantation for multiple myeloma (MM) is clearly correlated with progression-free and probably also overall survival. Thus a major goal of all protocols for the treatment of younger patients with MM is to achieve a chest radiogram (CR). Recent data of the Spanish myeloma study group reveal long-term disease free survival in a subgroup of patients with CR after autologous stem cell transplant (SCT).

Inclusion of novel agents (thalidomide, portezomib or lenalidomide) in the induction regimens prior to stem cell harvest and transplantation has allowed to achieve better remission quality prior to and after autologous SCT and to reduce treatment-related mortality. Recently also protocols containing 2 novel agents have been used to improve induction regimens for patients with multiple myeloma.

In this study the PETHEMA/GEM group has studied and compared 3 induction regiments VTD (2 novel agents), TD and VBMCP/VBAD (an intensive regimen with bortezomib). VTD showed the best equality of remission (CR rate $35 \%$ vs $14 \%$ with TD and $21 \%$ with VBMCP/VBAD/B. Also the PFS after VTD plus autologous SCT was significantly longer when compared two both other induction protocols. Unfortunately $14 \%$ of the patients in the VTD arm developed grade 3 and 4 PNP. Thus, future studies should use either bortezomib or proteosome inhibitors with a lower neurotoxicity.

In addition, the VTD regimen in contrast to the GIMEMA study was not able to overcome the poor prognostic impact of high risk cytogenetics. Thus other treatment strategies e.g. allogeneic SCT, novel IMiDs or PI should be evaluated in these high risk MM patients (17p del, 7(4;14)).

Competing Interests: No competing interests were disclosed.

I confirm that I have read this submission and believe that I have an appropriate level of expertise to confirm that it is of an acceptable scientific standard. 
Reviewer Report 07 November 2012

https://doi.org/10.5256/f1000research.201.r315

(C) 2012 Waheed S. This is an open access peer review report distributed under the terms of the Creative Commons Attribution License, which permits unrestricted use, distribution, and reproduction in any medium, provided the original work is properly cited.

\section{Sarah Waheed}

Myeloma Institute for Research and Therapy, University of Arkansas for Medical Sciences, Little Rock, AR, USA

The author has failed to mention if this patient had ever received any chemotherapy previously and if they did what agents were used. Also what was the initial presentation of myeloma in this patient?

The only imaging modality used was a Chest X-ray, it would have been helpful to know if a CT scan was done to evaluate if any pleural based mass was present along with the pleural effusion.

Competing Interests: No competing interests were disclosed.

I confirm that I have read this submission and believe that I have an appropriate level of expertise to confirm that it is of an acceptable scientific standard, however I have significant reservations, as outlined above.

Reviewer Report 30 October 2012

https://doi.org/10.5256/f1000research.201.r313

(c) 2012 Jurczyszyn A. This is an open access peer review report distributed under the terms of the Creative Commons Attribution License, which permits unrestricted use, distribution, and reproduction in any medium, provided the original work is properly cited.

\section{Artur Jurczyszyn}

Department of Hematology, Jagiellonian University Medical College, Krakow, Poland

Competing Interests: No competing interests were disclosed.

I confirm that I have read this submission and believe that I have an appropriate level of expertise to confirm that it is of an acceptable scientific standard. 
The benefits of publishing with F1000Research:

- Your article is published within days, with no editorial bias

- You can publish traditional articles, null/negative results, case reports, data notes and more

- The peer review process is transparent and collaborative

- Your article is indexed in PubMed after passing peer review

- Dedicated customer support at every stage

For pre-submission enquiries, contact research@f1000.com 